\title{
Validation of the ovine fetus as an experimental model for the human myelomeningocele defect ${ }^{1}$
}

\author{
Validação do feto de ovino como modelo experimental \\ de meningomielocele
}

\author{
Denise Araújo Lapa Pedreira ${ }^{2}$, Rita de Cássia Sanchez e Oliveira ${ }^{3}$, Paulo Roberto Valente ${ }^{4}$, Rogério C. Abou- \\ Jamra $^{5}$, Andrezza Araújo ${ }^{6}$, Paulo Hilário Saldiva ${ }^{7}$ \\ 1. Study performed at Experimental Surgery Department of Dante Pazzanese Institute of Cardiology and Pathology Department of Faculty of Medicine, \\ University of São Paulo (FMUSP), Brazil. \\ 2. PhD, Head of Fetal Medicine Team of Albert Einstein Hospital, São Paulo, Brazil. \\ 3. Fellow PhD degree, FMUSP, São Paulo, Brazil. \\ 4. Veterinarian, Chief of Experimental Surgery Laboratory, Dante Pazzanese Institute of Cardiology, São Paulo, Brazil. \\ 5. Veterinarian, Fellow Master degree, Experimental Physiopathology Department, FMUSP, São Paulo, Brazil. \\ 6. Veterinarian, Experimental Surgery Laboratory, Dante Pazzanese Institute of Cardiology, São Paulo, Brazil. \\ 7. Chairman of Pathology Division, FMUSP, São Paulo, Brazil.
}

\begin{abstract}
Purpose: To produce a myelomeningocele-like human defect in the ovine fetus and validate this experimental model in our population. Methods: A prospective study on 12 pregnant sheep of a crossed Hampshire/Down breed where a spinal defect was surgically created between Day 75 and Day 77 after conception. The technique consisted of a hysterotomy with exposure of fetal hind limbs and tail up to the mid spine. Fetal skin, paravertebral muscles, and 4 posterior spinal arches were excised, exposing the spinal cord. Duramater was opened and the medulla was incised until the medullar canal. Animals were euthanized at 139 days of gestation for fetal evaluation. The central nervous system was submitted to post-mortem magnetic resonance imaging (MRI) and the spine was submitted to pathological examination. Results: The defect was created in 13 fetuses and 5 survived. Mean gestational age at necropsy was 121.6 days (varying from 93 to 145 days). Macroscopically, the defect was present in 4 cases. Microscopy revealed a flattened medulla with disappearance of the medullar canal and disruption of normal medullar architecture with neuronal apoptosis and/or fusion of the piamater and duramater. The MRI showed herniation of the cerebellum into the cervical canal and syringomyelia. Conclusions: The surgically produced defect mimics the defect found in the human fetus, including the Arnold-Chiari malformation. Post-mortem MRI was used for the first time in our study and proved an excellent alternative for demonstrating the cerebellar herniation. We standardized the technique for creating the defect in our population. Keywords: Models animal. Meningomyelocele. Spinal dysraphism. Fetus. Sheep.
\end{abstract}

\section{RESUMO}

Objetivo: Produzir um defeito semelhante a meningomielocele humana em feto de ovinos, validando este modelo experimental, em nosso meio. Métodos: Estudo prospectivo com 12 ovelhas de cruzamento das raças Hampshire e Down, onde um defeito na coluna foi criado cirurgicamente com 75 a 77 dias de gestação. A técnica consistiu em histerotomia com exposição das patas traseiras e cauda até a metade da coluna fetal. Foram retirados pele, musculatura paravertebral e 4 arcos vertebrais posteriores, expondo a medula. A dura foi aberta e uma incisão até o canal medular foi realizada. O sacrifício foi realizado com 139 dias de gestação para avaliação fetal. O sistema nervoso central foi submetido a ressonância magnética (REMA) post-mortem e a coluna foi submetida a exame anátomo-patológico. Resultados: O defeito foi criado em 13 fetos e 5 sobreviveram. A idade gestacional média da necropsia foi de 121,6 dias (variando de 93 a 145 dias). Macroscopicamente o defeito estava presente em 4 casos. A microscopia revelou achatamento da medula, com desaparecimento do canal medular e desarranjo da citoarquitetura medular com apoptose neuronal e/ou fusão da pia e dura-máter. A REMA demonstrou herniação do cerebelo para o canal cervical e siringomelia. Conclusões: O defeito produzido foi muito semelhante à meningomielocele em fetos humanos, levando inclusive à mal-formação de ArnoldChiari. A REMA post-mortem, utilizada de forma inédita neste estudo, demonstrou ser uma excelente alternativa para demonstrar a presença da herniação do cerebelo. A técnica para produzir o defeito foi padronizada em nosso meio. Descritores: Modelos animais. Meningomielocele. Disrafismo espinhal. Feto. Ovinos. 


\section{Introduction}

Myelomeningocele is a devastating disease that can lead to hydrocephalus, mental retardation, motor deficiency, and urinary/fecal incontinence. Postnatal treatment offers few possibilities for improvement in affected newborns, and prenatal treatment seems a reasonable alternative. There is evidence that the earlier the spinal cord can be enclosed, the smaller the degree of mechanical and chemical damage to it ${ }^{1-7}$. The surgical correction already performed in some human fetuses has also demonstrated the possibility of reversal of the posterior herniation of the cerebellum known as Type II Arnold-Chiari malformation ${ }^{1-3}$. This herniation is responsible for the development of hydrocephalus, present in about $70 \%$ of myelomeningocele cases ${ }^{1-2}$. The possibility of improving the neurological condition with prenatal surgical correction of myelomeningocele was first demonstrated in an animal model ${ }^{(4-6)}$ and the technique has been applied in humans since then ${ }^{1-2}$. However, this correction has used the "open surgery" approach, a very aggressive technique for both the mother and the fetus. Authors who use this approach perform the correction using the classic neurosurgical technique of closing the spinal cord and adjacent tissues by layers, in an attempt to reconstitute normal spinal cord anatomy. With the objective of utilizing the endoscopic approach in correcting myelomeningocele, we attempted to simplify the classic neurosurgical technique, which we consider difficult to employ via endoscopy. To do so we used the rabbit fetus, and in the first study ${ }^{8-9}$, we modified the defect-producing technique. In the second study ${ }^{10}$, we successfully developed a new corrective technique, using cellulose film to cover the deformity. Because of its similarity with the human fetus in size and anatomy, the ovine fetus has been the animal model of choice for developing new techniques in fetal surgery ${ }^{7,11-18}$. Therefore, this corrective technique should be subsequently applied in ovine fetuses. The surgical correction of the defect in the sheep fetus initially used the technique described by Meuli et al. ${ }^{7}$ and modified by Paek et al. ${ }^{3}$. This study intends to describe the pilot phase of this project in which we validate, for the first time in our population, the surgical creation of myelomeningocele in an ovine fetus.

\section{Methods}

Twelve pregnant mixed breed Hampshire sheep were obtained from an external breeder. Gestational age was guaranteed by intra-vaginal insemination during the natural estrous of the animals, which occurs twice a year. Transport from the farm to the laboratory was made at least 7 days before surgery, in order to allow the animals to adapt to their new environment, a semi-open pen with natural day/night variations. Before surgery, the animals were submitted to a 48-hour food and 24-hour fluid fast. While still in the pen, the pre-anesthetic medication was given ( $1 \%$ acepromazine 0.2 to $0.4 \mathrm{mg} / \mathrm{Kg}$ and midazolam 0.3 to $0.5 \mathrm{mg} / \mathrm{Kg}$, IV) and the animals were taken to the surgical center under sedation. Hair removal was performed before entering the operating room. Anesthesia was supplemented by intravenous thiopental 7.5 to $10 \mathrm{mg} / \mathrm{Kg}$ followed by orotracheal intubation, and maintained with 2\% halothane. Enrofloxacin $5 \mathrm{mg} / \mathrm{Kg}$, was then applied for antibiotic prophylaxis. Total fluids given during the operation and post-anesthesia recovery period were approximately $15 \mathrm{~mL} / \mathrm{Kg} / \mathrm{h}$ of $0.9 \%$ saline, containing $15 \mathrm{mg} / \mathrm{Kg} / \mathrm{h}$ glucose.

\section{Technique for creation of defect}

During the initial phase, a deformity similar to myelomeningocele was surgically produced in the fetal spine at Day 72 to Day 75 of gestation. After becoming standardized, it was performed between Day 75 and Day 77 of gestation. Following infraumbilical antisepsis and asepsis, a $15 \mathrm{~cm}$ left para-mammary incision in the lower maternal abdomen was performed, followed by opening by layers of two aponevroses, muscles, and peritoneum. The uterus was exteriorized and accommodated with the placement of a cushion made of sterile surgical drapes. Fetal position was determined by palpation; a transuterine ultrasound, with a transducer protected by a sterile plastic sheath, was performed to verify fetal heart rate (FHR). Hysterotomy was made immediately above the site where the fetal lumbar spine was palpated. Two stay stitches using 2-0 vicryl were placed in the uterine wall with a 5-cm interval between then, and an opening was made with an electrical scalpel between these stitches. Next, the membranes were opened with scissors, and $100 \mathrm{~mL}$ of amniotic fluid was removed, using 20 $\mathrm{mL}$ syringes maintained in a heated saline bath. Upon palpation of iliac crests, at this point the skin was excised over the spine in the cranial direction, extending $3.0 \mathrm{~cm}$ long and $1.5 \mathrm{~cm}$ wide. A paramedian incision was performed with a scalpel to separate paravertebral muscles from spinous processes bilaterally, followed by manual dissection with gauze for further removal with scissors, bilaterally. Next, intervertebral space palpation and transversal incision to the medullar canal were performed. Spinous processes were grasped with forceps, and scissor dissection penetrated to the medullar space bilaterally, allowing resection of three to four lumbar vertebrae (Figure 1). Duramater was opened with a scalpel or $30 \times 7$ needle, with visualization of CSF leakage and a central incision was made in the medullar canal, exposing nerve tissue. Fetus was returned to uterus, fetal heartbeats were checked, single-layer hysterorhaphy was performed, including membranes, with invaginating continuous stitches, and restitution of amniotic fluid stored in syringes was made. Fetal 
heartbeats were checked again and the uterus was replaced in the maternal abdominal cavity. The peritoneum, muscles, and aponevroses were closed in a single layer, the superficial aponevroses in a second layer, and the skin in a third layer. Fetal heartbeats were checked once again, as well as after anesthetic recovery and animal was returned to the pen. Fetal vitality was reevaluated by weekly ultrasonography until the animals were euthanized.

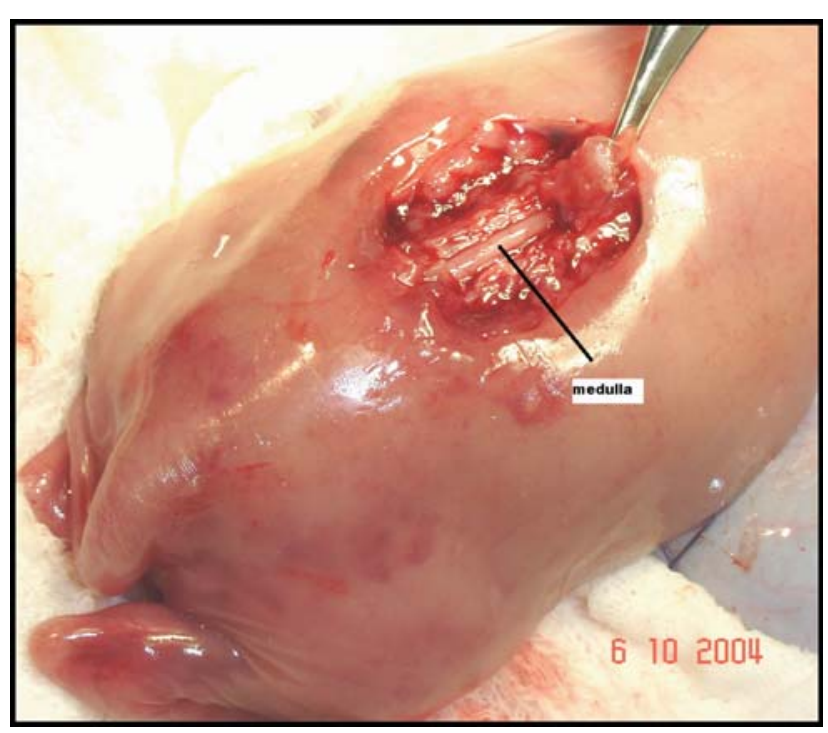

FIGURA 1 - Aspect of the exposed fetal medulla during surgery, after paraspinal muscles and three spinal processes have being removed (forceps). At the creation of the defect, 75 days of gestation

\section{Euthanasia}

According to the protocol approved by the institutional Research Ethics Committee, the animals were initially euthanized at Day 145 of gestation, and posteriorly at Day 139 of gestation. For this, the same anesthetic protocol as above was used, except for orotracheal intubation and use of halothane. The dose of thiopental was increased to $20 \mathrm{mg} / \mathrm{Kg}$, assuring maternal and fetal sedation. After a few minutes, $0.4 \mathrm{~mL} /$ $\mathrm{Kg}$ of KCL $19.1 \%$ bolus was injected into the maternal circulation. After cessation of maternal heart beats, abdominal wall and uterus were opened. If fetal heartbeats were still present, bolus KCL was also injected into the fetal circulation until cardiac arrest. Fetal weight was checked, and fetuses were photographed and placed in $10 \%$ formalin. Specimens were then submitted to magnetic resonance imaging of the CNS and spine, and posteriorly the fetal column block was removed for pathological evaluation.

\section{Results}

The study was divided into two phases: initial phase in which the technique for creating the spinal defect, anesthesia, and handling of the animals was still being tested, and the final phase when all these techniques had been standardized. According to these phases, the animals were divided into two groups, the pilot group, and the case group, respectively. Of the 12 sheep operated, the spinal defect was created in 13 fetuses, since in one twin gestation both fetuses received surgery. Eight fetuses were operated in the pilot group, and 5 in the case group. There was one maternal/fetal death immediately after defect was created in the pilot group. The weekly ultrasound evaluation proved to be of little value, since in most fetal losses, spontaneous delivery/ miscarrige occurred before the ultrasonographic diagnosis of fetal death was made. In live fetuses, ultrasound evaluation showed a normal amount of amniotic fluid. Nevertheless, premature labor occurred subsequent to the ultrasound in some cases, and we decided to perform the scan only when clinically indicated. Assessment of the cause of fetal deaths was also more difficult since all fetuses were macerated at the time of expulsion, precluding a pathological evaluation or the performance of tissue cultures (deliveries occurred in the pens, during the night, without assistance). Overall survival was 5 cases from a total of 13 (38.5\%); 3 fetuses survived in the pilot group and 2 in the case group (Table 1). In these fetuses, no signs suggestive of bacterial infection was detected. Premature labor occurred in 2 of 4 fetuses that survived, in gestations that were maintained to term since one fetus was euthanized at Day 98 of gestation in order to evaluate the depth of the deformity created. These births happened at Day 93 and Day 133 in two twin subsequent gestations after the death of the other twin. The elevated rate of prematurity led us to euthanize the last case seven days earlier, which happened on Day 139 of gestation. The mean gestational age at euthanasia was 121.6 days, varying from 93 to 145 days. Macroscopically, the defect was present in 4 cases at birth (Figure 2), since in one case there was complete closure of the skin over the defect. The interval between creation of the defect and birth was, on average, 46 days (varying from 16 to 70 days). Microscopy revealed spinal cord nerve tissue exposure (except in cases where the skin had healed) and disappearance of normal spinal cord cell architecture, with the presence of inflammatory cells, neuronal apoptosis, flattening of the spinal cord (Figure 3 ), and disappearance of the spinal cord canal. There was fusion of piamater and duramater in 3 of the 4 cases analyzed (in one case, the "specimen" was lost). Magnetic resonance imaging showed herniation of the cerebellum to the cervical canal (Arnold-Chiari malformation) in one of three cases in which it was 
performed (Figure 4). In one case, at the lesion site, no spinal cord tissue was seen (total destruction) and syringomyelia (dilation of the spinal cord canal) was observed in another case.

TABLE 1 - Follow-up of the operated cases were a spinal defect was created in the fetal spine during all the study phases

\begin{tabular}{llllllll}
\hline Group & $\begin{array}{l}\text { Animals } \\
(\mathrm{n})\end{array}$ & $\begin{array}{l}\text { Fetus } \\
(\mathrm{n})\end{array}$ & $\begin{array}{l}\text { Maternal } \\
\text { death }(\mathrm{n})\end{array}$ & $\begin{array}{l}\text { Premature } \\
\text { delivery }\end{array}$ & $\begin{array}{l}\text { Necropsy } \\
\text { (dias) }\end{array}$ & $\begin{array}{l}\text { Alive } \\
(\mathrm{n})\end{array}$ & Survival \\
\hline Pilot & 7 & $8(1$ twin $)$ & 1 & 2 & 93 a 133 & 3 & $30 \%\left(3 / 7^{*}\right)$ \\
Cases & 5 & 5 & - & 0 & 139 e 145 & 2 & $62,5 \%(2 / 5)$ \\
Total & 12 & 13 & & $2(2 / 4 * *)$ & & 5 & $5 / 13(38,5 \%)$ \\
\hline
\end{tabular}

*the fetus was excluded due to maternal death

** the fetus was excluded due to the early sacrifice at 98 days

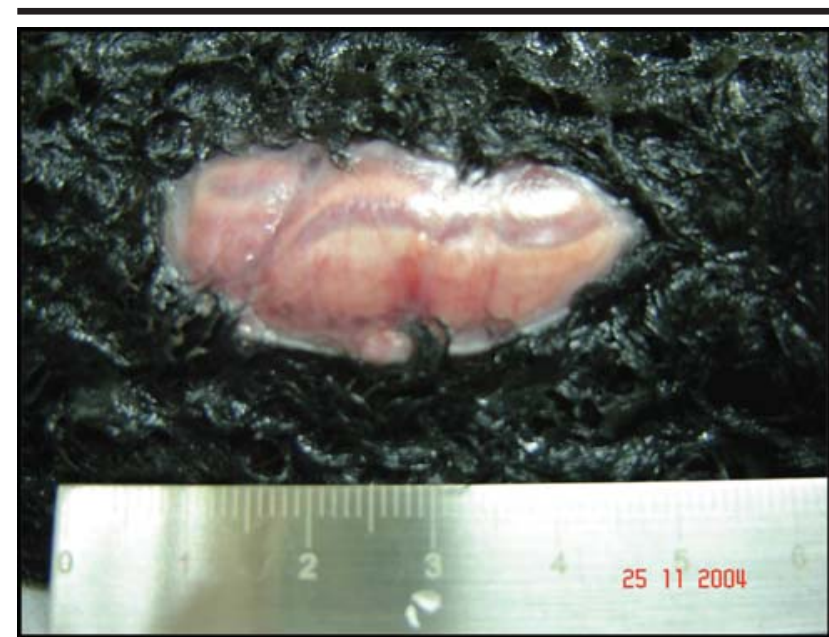

FIGURA 2 - Postnatal macroscopic aspect of the spinal defect at 139 days of gestation. Note the opened skin and the exposed medulla

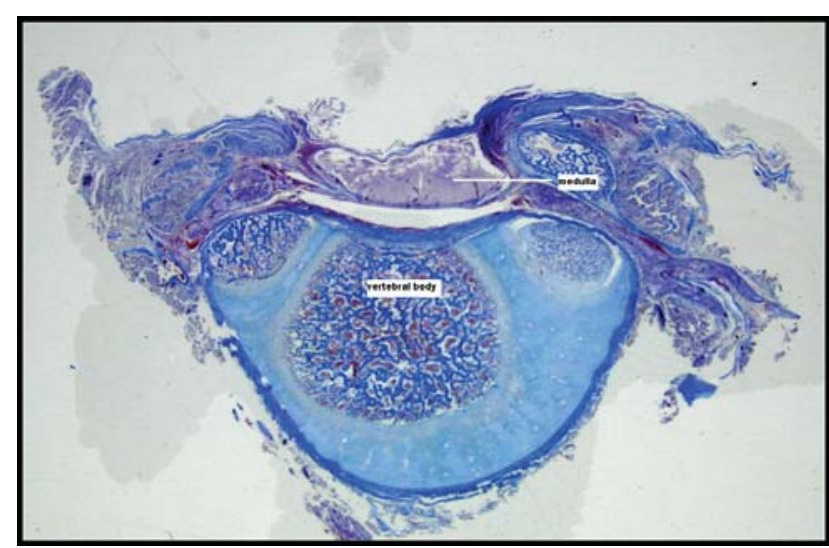

FIGURA 3 - Pathological aspect of the spinal defect, note the flat exposed medulla, the disappearance of the central canal and the derangement of normal citoarchitecture of the medulla

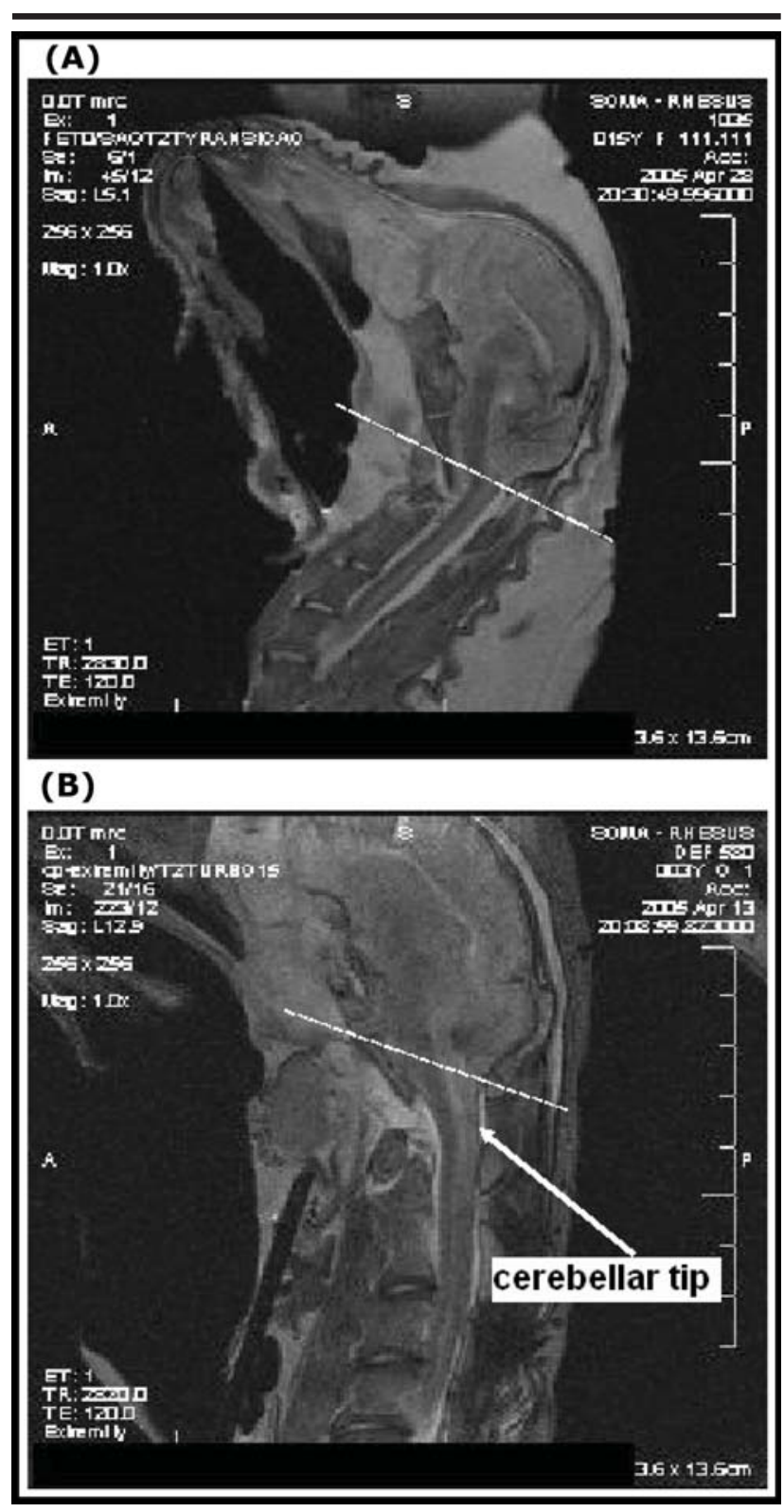

FIGURA 4 - Postmorten magnetic ressonance immaging of fetal brain in logitudinal view. (A) Note the cerebellar (arrow) herniation into the spinal canal, Arnold-Chiari malformation. (B) Normal position of the cerebelum, above the major forame, in a case where there was no herniation (dotted line) 


\section{Discussion}

At the beginning of our study, only one group of researchers had standardized ${ }^{11}$ and later modified, with the opening of the central canal of the spinal $\operatorname{cord}^{3}$, the technique for creating a defect similar to myelomeningocele in ovine fetuses. In these two studies, fetal mortality varied between $47 \%$ and $50 \%$, respectively, while in our series this number reached $60 \%$. This difference might be because our data included the pilot phase of our study, when we had not yet reached the learning curve plateau regarding surgical, anesthetic, and animal management aspects. In our study, similar to these other two trials, we were not able to clarify the causes of fetal death. We believe that they could not be explained because of characteristics inherent to projects using animal models, such as the absence of a clinical complaint of cessation of fetal movements. This precludes removal of the fetus after its death, and its permanence in the uterus ultimately leads to maceration. The anatomopathological evaluation, which would be essential in order to identify causes of death, is impossible in a macerated fetus. On the other hand, if we tried to daily monitor fetal heart beats to allow fetal removal before maceration, this would increase the animal's stress and could lead to premature labor. The difficulty in establishing the causes of death hinders evaluating factors for the long-term survival improvement observed in our study, but some aspects can be discussed. We believe that the increase in minimum gestational age for creating the defect, which initially was 73 days and was changed to 75 days of gestation, may have increased fetal survival. Our impression is that the earlier in the pregnancy the defect was created, the greater the fetal mortality. The study by Eggink et al. ${ }^{18}$, seems to corroborate these findings, since these authors also delayed creating the defect until Day 79 of gestation, whereas in the studies carried out by Meuli et al. ${ }^{11}$ and Paek et al. ${ }^{3}$ the euthanization date had been set at Day 75 of gestation. In reducing animal stress, transport at a pre-established time must be remembered. Ideally, the animals would leave the farm at 16:00, arriving in São Paulo city after 20:00, thus avoiding peak traffic at the entrance of the city and excessive heat in daytime transportation. Another measure to be kept in mind is the need for a gradual feeding change from grazing meadows to feed while the animals are still on the farm, before being sent to the laboratory. Prematurity occurred in half of the cases of our study, similar to what happened in the study performed by Von Koch et al. ${ }^{17}$ in which it was also seen in 50\% of cases. Therefore, we chose to anticipate euthanasia to Day 139, similar to what these authors did. Additionally, over the duration of the study, we modified the flooring of the pens, placing wood slats over the base thus preventing direct contact of the animals with a cold floor. We believe that this measure reduced prematurity, besides facilitating the maintenance of local sanitation. Another modification made was an increase in the interval between postoperative ultrasound observations of the fetuses, which initially was weekly and was changed to only when necessary because of maternal bleeding or doubts as to fetal vitality. This was done in order to avoid the stress of the restriction necessary for positioning the gravid sheep without sedation, a fact that seemed to lead to premature labor. We also chose to reduce examination time, avoiding fetal biometry and merely observing fetal vitality as necessary. Still another measure adopted was to avoid including twin gestations, besides operating on only one fetus when the double gestation was not diagnosed before surgery. This proved to be important since in two cases we believe that prematurity occurred by premature labor being setoff by the death of the other twin. In assessing the presence of Arnold-Chiari malformation associated with the spinal defect, our study demonstrated for the first time, the success of post-mortem magnetic resonance in order to evaluate herniation of the cerebellum. In no previous study had the use ${ }^{3,14,16}$ of magnetic resonance been employed. In all these studies, the authors based their observations on analyses of the anatomical specimen, which is a lot more troublesome to prepare than what is needed to submit the samples to resonance, in our study. After the beginning of our study, four more studies were published in which myelomeningocele was surgically created in a sheep fetus, three of them from the same group of authors in San Francisco, United States $^{14-16,18}$. All of them demonstrated that the defect created by this technique is histologically similar to myelomeningocele in humans. Nevertheless, this technique had not yet been reproduced and standardized in our country. The anatomopathological aspect of the defect created in our study was very similar to what is found in the human fetus and the defect produced in other studies using an ovine fetus, allowing a validation of the defect creating technique in our country. This will make it possible for the surgeon, when correcting this defect a few days after its creation, to work with technical challenges similar to those present in the human fetus with myelomeningocele. The techniques and materials currently used to correct myelomeningocele in human fetuses will be perfected allowing the use of the endoscopic route in correcting this defect.

\section{Conclusion}

Modifications performed during this study allowed an improvement in fetal survival. The defect produced was very similar to that of myelomeningocele in human fetuses, including the Arnold-Chiari malformation. The sheep fetus can be used as an experimental model for the study of this defect. The technique for producing the spinal opening defect was successfully standardized in our country. 


\section{References}

1. Bruner JP, Tulipan N, Paschall RL, et al. Fetal surgery for MMC and the incidence of shunt-dependent hydrocephalus. J Am Med Assoc. 1999; 1819-25.

2. Sutton LN, Adzick NS, Bilanuik LT et al. Improvement in hindbrain herniation demonstrated by serial fetal MRI following fetal surgery for myelomeningocele. J Am Med Assoc. 1999; 282:1826-31.

3. Paek BW, Farmer D, Wilkinson C, Craig TA, Peacock W, Harrison MR, Jennings RW. Hindbrain herniation develops in surgically created myelomeningocele but is absent after repair in fetal lambs. Am J Obstet Gynecol 2000;183:1119-23.

4. Michejda M. Intrauterine treatment of spina bifida: primate model. Z Kinderchir. 1984; 39:259-61.

5. Heffez DS, Aryanpur J, Hutchins, Freeman JM. The paralysis associated with myelomeningocele: clinical and experimental data implicating a preventable spinal cord injury. Neurosurgery. 1990; 26:987-92.

6. Meuli M, Meuli-Simmen C, Hutchins GM, Seller MJ, Harrison MR, Adzick NS. The spinal cord lesion in human fetuses with myelomeningocele: implications for fetal surgery. J Pediatr Surg 1997; 32:448-52.

7. Meuli M, Meuli-Simmen C, Yingling CD, Hutchins GM, Timmel GB, Harrison MR, Adzick NS. In utero repair of experimental myelomeningocele saves neurological function at birth. J Pediatr Surg. 1996; 31:397-402.

8. Pedreira DA, Valente PR, Abou-Jamra RC, Pelarigo CL, Silva LM, Goldenberg S. A different technique to create a 'myelomeningocele-like' defect in the fetal rabbit. Fetal Diagn Ther. 2002;17(6):372-6.

9. Pedreira DA, Valente PR, Abou-Jamra RC, Pelarigo CL, Silva LM, Goldenberg S. Estudo de uma nova técnica para criação cirúrgica de um defeito semelhante a meningomielocele em fetos de coelhos. Acta Cir. Bras. 2003;18(2):125-31.

10. Pedreira DA, Valente PR, Abou-Jamra RC, Pelarigo CL, Silva LM, Goldenberg S. Successful fetal surgery for the repair of a 'myelomeningocele-like' defect created in the fetal rabbit. Fetal Diagn Ther. 2003;18(3):201-6.
11. Meuli M, Meuli-Simmen C, Yingling CD, Hutchins GM, Hoffman KM, Harrison MR, Adzick NS. Creation of myelomeningocele in utero: a model of functional damage from spinal cord exposure in fetal sheep. J Pediatr Surg. 1995; 30:1028-32.

12. Meuli-Simmen C, Meuli M, Hutchins GM, Harrison MR, Buncke HJ, Sullivan KM, Adzick NS. Fetal reconstructive surgery: experimental use of the latissimus dorsi flap to correct myelomeningocele in utero. Plast Reconstr Surg 1995; 96:1007-11.

13. Bruner JP, Richards WO, Tulipan NB, Arney TL. Endoscopic coverage of fetal myelomeningocele in utero. Am J Obstet Gynecol. 1999; 180:153-8.

14. Bouchard S, Davey MG, Rintoul NE, Walsh DS, Rorke LB, Adzick NS. Correction of hindbrain herniation and anatomy of the vermis after in utero repair of myelomeningocele in sheep. J Pediatr Surg. 2003;38(3):451-8.

15. Kohl T, Hartlage MG, Kiehitz D, Westphal M, Buller T, Achenbach S, Aryee S, Gembruch U, Brentrup A. Percutaneous fetoscopic patch coverage of experimental lumbosacral full-thickness skin lesions in sheep. Surg Endosc. 2003;17(8):1218-23.

16. Yoshizawa J, Sbragia L, Paek BW, Sydorak RM, Yamazaki Y, Harrison MR, Farmer DL. Fetal surgery for repair of myelomeningocele allows normal development of anal sphincter muscles in sheep. Pediatr Surg Int. 2004;20(1):14-8.

17. von Koch CS, Compagnone N, Hirose S, Yoder S, Harrison MR, Farmer DL. Myelomeningocele: characterization of a surgically induced sheep model and its central nervous system similarities and differences to the human disease. Am J Obstet Gynecol. 2005;193(4):1456-62.

18. Eggink AJ, Roelofs LA, Feitz WF, Wijnen RM, Mullaart RA, Grotenhuis JA, van Kuppevelt TH, Lammens MM, Crevels AJ, Hanssen A, van den Berg PP.In utero repair of an experimental neural tube defect in a chronic sheep model using biomatrices. Fetal Diagn Ther. 2005;20(5):335-40.

\section{Aknowlegments}

We wish to thank Dr. Leopoldo Soares Piegas and Dr. Álvaro Avezum for their support and specially Isaías and Wanderley for their care with the animals during the study period.

\section{Correspondence:}

Denise Araújo Lapa Pedreira

Rua Bagé, 163/182

04012-140 São Paulo - SP Brazil

wdpedreira@uol.com.br
Conflict of interest: none Financial source: FAPESP

Received: January 25, 2007

Review: February 21, 2007

Accepted: March 19, 2007

How to cite this article

Pedreira DAL, Oliveira RCS, Valente PR, Abou-Jamra RC, Araújo A, Saldiva PH. Validation of the ovine fetus as an experimental model for the human myelomeningocele defect. Acta Cir Bras. [serial on the Internet] 2007 May-June;22(3). Available from URL: http://www.scielo.br/acb 